\title{
蛇紋岩の土木地質的一検討
}

$$
\text { 梅 津 一 晴* }
$$

\section{An Engineering Geological Study for Serpentine}

\section{Kazuharu UMETSU*}

\author{
Key words : 蛇紋岩化作用 serpentinization, 滑石 talc, Mg 緑泥石 Mg-chlorite, \\ 膨張性土圧 swelling pressure
}

\begin{abstract}
Serpentines occur in ultrabasic dykes, ophiolitic complexes, melanges, etc..

The author has classified serpentinization, based on the above occurrences, into 4 types. Type A is the Serpentines that occurs in dykes, type $B$ occurs in complexes, type $\mathrm{C}$ occurs in serpentine melanges, and type $\mathrm{D}$ occurs in the sedimentary melanges.

Further classification established 3 alteration grades of serpentinization. Alteration grade $-I$ is the forming serpentinite (massive serpentine), alteration grade - II is forming of foliation or shearing by the tectonic movement, and alteration grade - III is the talc-chlorite alteration by the regional metamorphism.

It might be shown that hard constructions in the serpentine areas are owing to the alteration grade - II zone.

Chrysotile and antigorite in serpentinite causes serious unsymmetrical pressures and deformations in rocks, since they have the peculiar characteristics of swelling and viscosity, and that causes land-slides near land cuttings in Serpentine areas. Talc and Mg-chlorite, as clay minerals belong to the same Phyllosilicates ,also show similar characteristics to Serpentinite. Mg-chlorite has characteristics of swelling. The axis perpendicular to the foliation plaine of the serpentinized rock is considered to be maximum principal axis of swelling pressure.
\end{abstract}

\section{1. 緒言}

蛇紋岩は主にカンラン岩が変質して生じた岩石である が，粘土〜葉片状をなしていることが多い。 蛇紋岩の主要組成鉱物のクリソタイル, アンチゴライ トは, フィロ珪酸塩鉱物特有の葉片状剝離性と風化, あ るいは吸水して粘土化しやすい性質がある。そのため切 り土工事, トンネル工事等の土木工事中に, 蛇紋岩は膨 張性土圧を発生させ,ささらに水が供給されると圧砕部は

*応用地質㑣計測技術研究所 OYO CORPORATION, Instruments Division

現: $\mathbf{T} 270-11$ 我孫子市若松 $170-11$
塑性流動を生じることがあるため，常に土木地質学上， その分布状況と性状の把握が問題になる岩石である。 蛇紋岩は変質を受けた岩石であるため判別のむずかし い岩石である。筆者は蛇紋岩とはいかなる変質岩かと言 う問いからスタートし，全国の蛇紋岩の産状と蛇紋岩化 作用については文献により, 九州北部の三郡变成岩地域 の蛇紋岩については筆者がかって行った土木地質調查資 料を基に, 産状と蛇紋岩化作用について検討した。

また，我が国の代表的な蛇紋岩地帯のトンネル工事で 遭遇した蛇紋岩の工学的性質と, 筆者の調査による三郡 変成岩中の蛇紋岩の性状を示し, 加えて蛇紋岩に伴う変 質鉱物の粘土鉱物学的検討を行った。まとめとして，蛇 
紋岩の産状と変質について土木地質的見地から形態分類 を試みた。

この報告が蛇紋岩地帯での地質調査の際の参考になれ ば幸いである。

\section{2. 日本の超塩基性岩}

\section{1 蛇紋岩}

蛇紋岩の主な原岩である超塩基性岩のカンラン岩類は さまざまな状況の下で出現するが，キンバーライト，火 山岩中の包含物, 大洋中央海嶺の蛇紋岩を除いて大別す ると, 大陸型の層状貫入分化岩体や同心円状超塩基性複 合岩体に見られる大規模なカンラン岩類, そして造山帯 に貫入するアルプス型のカンラン岩がある。

我が国のカンラン岩類は造山帯に分布するアルプス型 に属し，大陸に見られる岩体に比べるとその規模は，は るかに小さい。その産状は岩脈, オフィオライト*1複合 岩体そして蛇紋岩メランジェ ${ }^{* 2}$, 堆積性メランジェと多 様である。

斎藤2)は1950年代における資源調查での蛇紋岩に関す る観察結果から蛇紋岩化作用を 2 期に分け, 次のよう に概略記述している。

蛇紋岩化作用は，第 1 期でカンラン石や斜方輝石の 蛇紋石による置換一葉片状アンチゴライトの形成一クリ ソタイルの形成の順に進むが，主に割れ目に沿って進行 する(いわゆる塊状蛇紋岩に相当すると理解される)。 第 2 期で蛇紋岩は貫入後の構造運動による 2 次的な強 い剪断・圧縮を受け，その構造と組織を破碎していわゆ る葉片状の蛇紋岩となり，さらに粘土化する。これに対 応してクリソタイルは, 繊維間を滑石によって充填ある いは置換されて脆弱となり, 緘維の形態を失う。

蛇紋岩化作用第 2 期でも滑石化が認められるが, 微 弱である例が多い。筆者は, 以下に述べる理由により, 福岡県三郡山北部地域結晶片岩中における蛇紋岩脈を中 心とする片岩化した滑石一緑泥石の変質累帯の形成は,

*1 オフィオライトと言う語は, Steinmann (1927) がアルプ 不造山帯に深海堆積物に伴って産する玄武岩, 斑れい岩, カンラン岩の複合岩体に用いたのが現代的用法の始まりで ある。70年代初頭に至り, オフィオライトは大陸衝突の縫 合線を示す地質時代の海洋地殼・マントルの断片として広 範な地球科学者から注目されるようになった (石渡 $\left.{ }^{1)}\right) 。$

*2 激しい剪断変形を受けて混合した岩石はメランジェと呼ば れる。蛇紋岩を主体にした中に異質な岩石を混合している ものを蛇紋岩メランジェと言う。スランピング等により砕 屑岩類とともに取り込をれた蛇紋岩の砕首岩は, 堆積性メ ランジェあるいはオリストストロームのものとされる。小 論では堆積性メランジェを用語とした。
第 2 期の構造運動とは異なる一段上の広域変成時の蛇 紋岩化作用によるものと考元, 第 3 期とすることにし た。そして蛇紋岩化作用に関する斎藤2)の考えを発展さ せ, 動力变成の程度を加味して, 塊状蛇紋岩を変質度 I, 葉片状〜粘土状蛇紋岩を変質度II, そして片岩化蛇 紋岩を変質度 III と表現することとした。

\section{2 三郡山北部の蛇紋岩化作用一変質度正について}

筆者が調查した福岡県三郡山北方には, 図- 1 の地質 図に示すように三郡变成岩が分布し，多数の蛇紋岩が貫 入している。また， $\mathrm{T} 川 に$ 平行する西北西一東南東方 向に軸を持つ三郡変成岩の背斜構造が認められる。図一 1 の南約 $100 \mathrm{~m}$ には, 図 -2 の右端南側に示す花崗岩の 貫入がある。

蛇紋岩は, 図-1に示すように図面の南北両端部をほ ほ東西に延びる, 幅 $100 \mathrm{~m}$ を越える $2 つ$ つ規模岩脈 (辻 ${ }^{3)}$ が言う複合岩体と考えられる）と，その間で大規 模岩脈と交差する方向に貫入する幅数 $\mathrm{m} \sim$ 十数 $\mathrm{m}$ の小 規模岩脈がある。図面南側の大規模岩脈は断層境界が認 められず, 周辺の変輝緑岩との区別も明確でない。小規 模岩脈は, 図- 2 に示す背斜構造北翼に片岩の片理面に 近い角度で貫入し, あるいは褶曲軸の走向に直角に近い NS 走向でほほ垂直に貫入する。NS 走向で貫入する蛇 紋岩の 1 つは, 図面東側で図 -2 の断面線と交差し, 他 の 1 つは図面西側に貫入し，ほとんど滑石化している。

これらの蛇紋岩は暗緑色〜黒色の堅固緻密な塊状の岩 石であるが, 岩脈自体も弱い片理構造を示し葉片状に破 断しやすい。この葉片状に破断する蛇紋岩はアクチノ閃 石, 緑泥石あるいは若干の滑石様鉱物を生じている。

蛇紋岩化作用に伴う変質作用は 2 種類ある。図 -3 の 模式図は南部の大規模岩体が図 -2 の東外側で劣化した 部分の断面図である。岩脈周辺の変輝緑岩, 角閃石片岩 には，多数のアンチゴライトと網目状割れ目に沿うクリ ソタイル脈, その他若干の滑石, アクチノ閃石が認めら れ，変質度 I を示している。

一方, 背斜構造北翼に貫入する小規模岩脈は变質度 II を示し, 葉片状〜粘土化が著しい。蛇紋岩の周辺部は, 図-4のように蛇紋岩岩脈を囲むように幅 $10 \mathrm{~m}$ 程度の 滑石片岩帯と, その外側に幅約 $20 \mathrm{~m}$ の滑石を含む緑泥 石片岩帯から成る变質累帯が形成されている。この変質 累帯は三郡変成岩の一部として片岩化し, 周辺の黒雲母 片岩の片理面にほぼ平行している。

この变質累帯の片岩化の形態は, 変質度 I, II 鉱物 集合形態とは異質であり, 変質度正の蛇紋岩化作用とし て分類したい。この変質度吕の蛇紋岩化作用は, 蛇紋岩 中の滑石生成が破砕帯, 裂か帯沿いに多いことから広域 


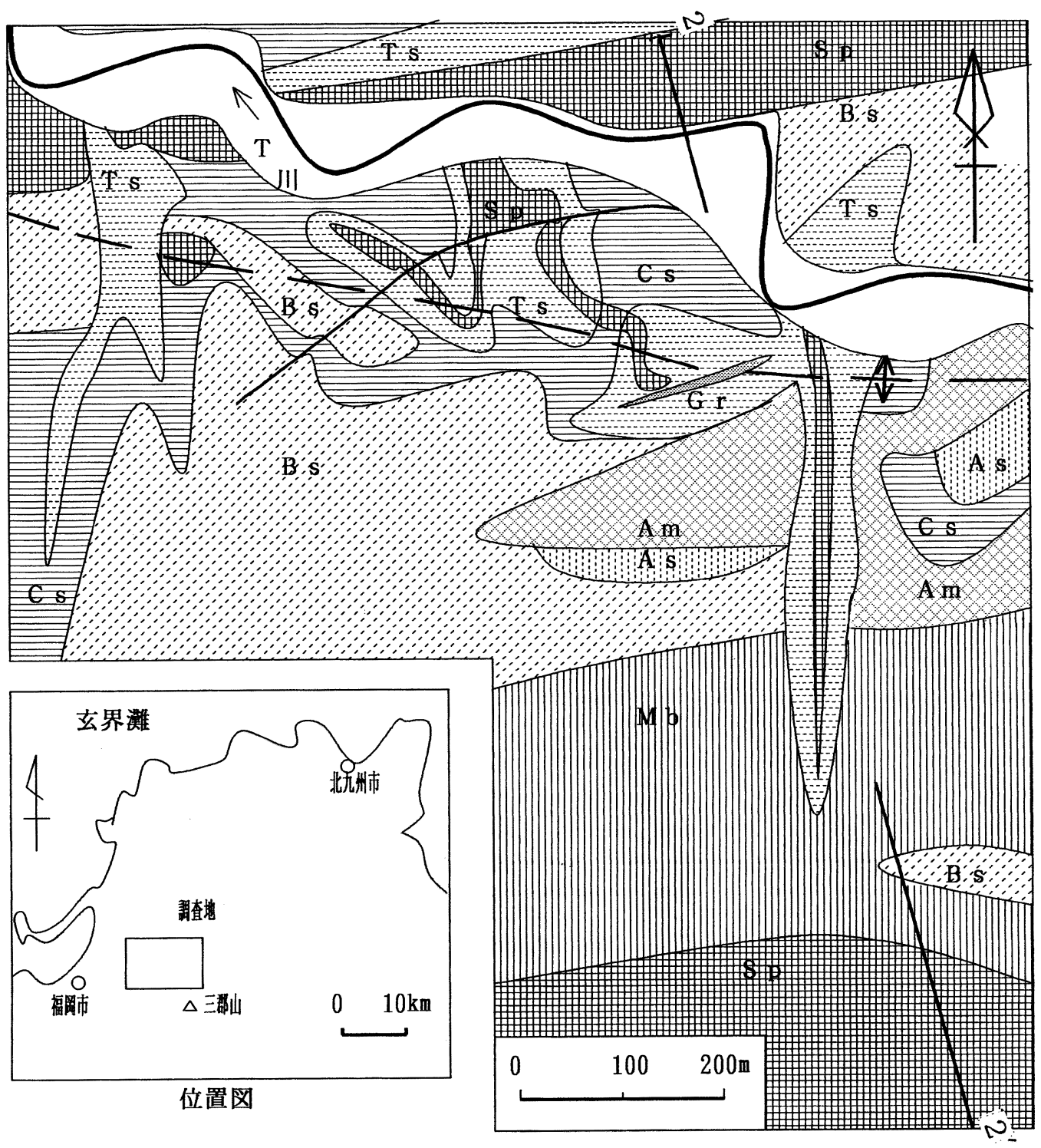

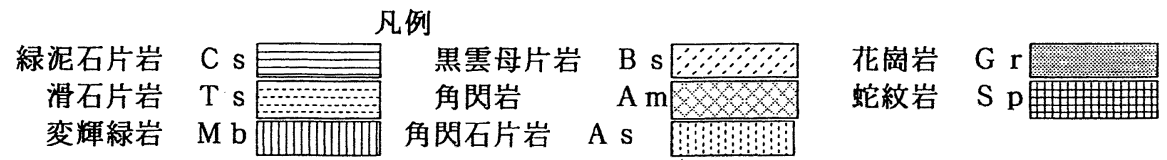

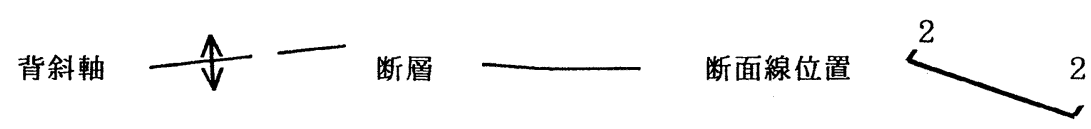

図-1 福岡県三郡山北部の地質図 


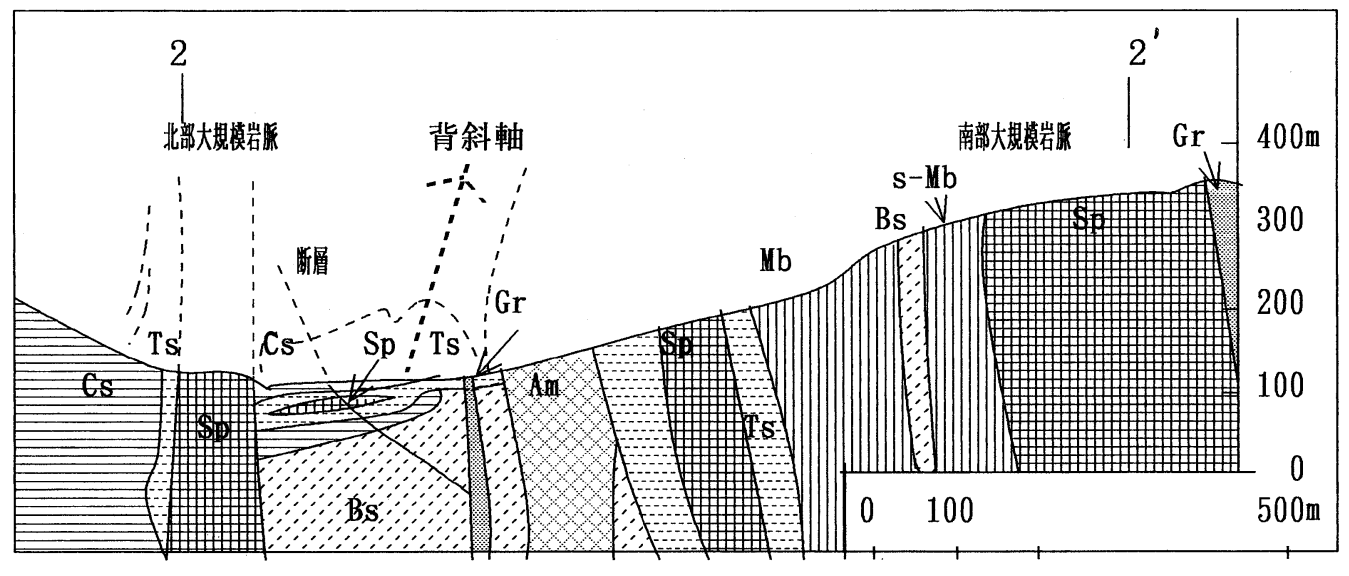

図-2 福岡県三郡山北部地域の南北地質構造断面図

蛇紋岩化 $\mathrm{s}$ -

注 困左の背斜軸北側の小規模蛇紋岩脈は, 垂直方向に拡大して表現した。実際の規模は図 -4 の規模である。

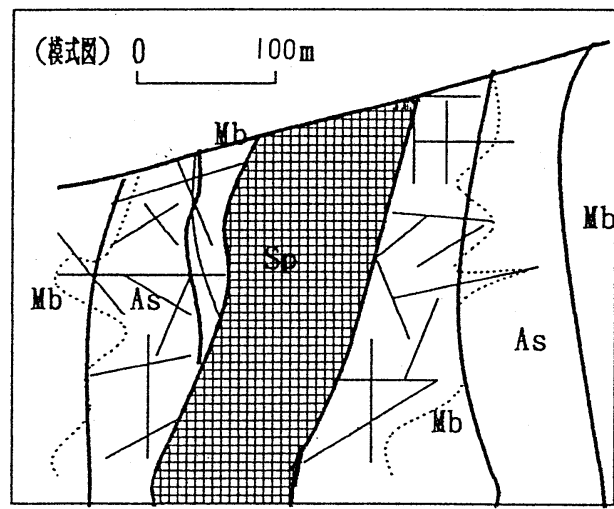

变質範井

将价 $>$

図 - 3 大規模岩脈周辺複合岩体の蛇紋岩化

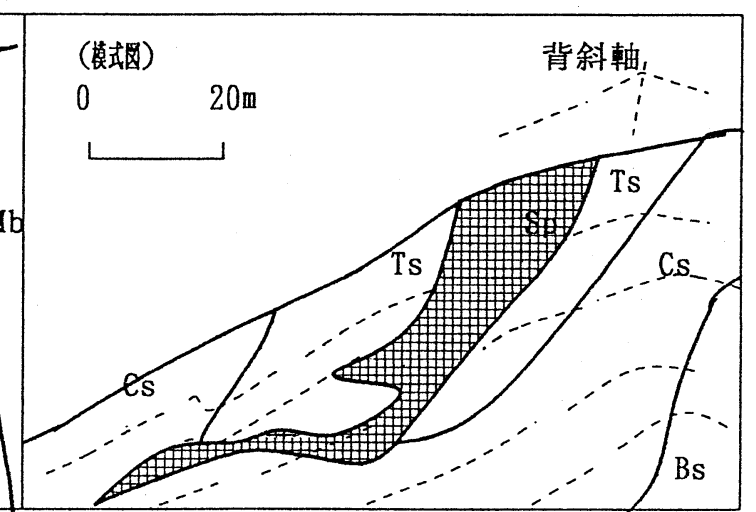

片理 -...

図-4 小規模岩脈の変質累帯

変成時の動力変成による蛇紋岩の片岩化と考えられる。

変質度III变質帯は, 滑石帯に限定してみると, 蛇紋 岩小規模岩脈の確認できる地区から離れて背斜軸沿いに 東西に延びている。その分布規模は幅 $250 \mathrm{~m}$, 延長約 $2 \mathrm{~km}$ に及ぶ。東方延長部の滑石帯は角閃岩をほぼ東西 に横断するが，角閃岩との接触部周辺の小範囲に限られ る。また，滑石帯は北部大規模岩脈の走向方向の割れ目 沿い，あるいは北側沿いにも進行している。

\section{3 各地の蛇紋岩とその変質度}

わが国のカンラン岩類の産状は, その変質岩である蛇 紋岩の産状に共通し，(A) 岩脈，（B）オフィオライト 複合岩体, (C) 蛇紋岩メランジェ, そして (D) 堆積 岩メランジェなどが知られている。

本文ではこれらの産状を以後, それぞれ A タイプ,
$\mathrm{B}$ タイプ, C タイプ, D タイプと呼び, 変質度 I, II, III と合わせて, 各構造帯の蛇紋岩の産状を以下で検討す る。

1) 神居古潭帯

蛇紋岩メランジェ中に捕獲された変成岩の接触部では 蛇紋岩は粘土化し，その境界はシャープである。葉片状 蛇紋岩はレンズ状の蛇紋岩ボールを多数伴う。変成鉱物 はアンチゴライト, クリソタイルを主とし, 滑石は量的 に少ない (NAGAWA, TODA $\left.{ }^{4)}\right)$ 。この場合, この蛇紋 岩はタイプCで, 変質度IIである。以後, $\mathrm{C}-$ II の変質 と表現する。

神居古潭帯南部の富内線地すべり地の地質は, 未分離 日高類層群と呼ばれる（酒井5)）黑色片岩を挟在する緑 色の凝灰岩である。蛇紋岩は断層に沿い貫入し，断層運 
動により大部分が破砕され粘土化していて(山田・他6)), $\mathrm{A}$ - II の変質である。

2）北上·阿武隈山地

岩手県遠野地方には，遠野花崗岩を挟むように南東か ら北西方向に延びる早池峰東縁断層と日詰一気仙沼断層 があって，それぞれの断層に東側を切られる形で，早池 峰と宮守の大規模な複合岩体が分布する (蟹沢・他 $\left.{ }^{7)}\right)$ 。

宮守滑石鉱床は，蛇紋岩の滑石化の著しい所で幅 30 $\mathrm{m}$, 延長 $40 \mathrm{~m}$ 規模の塊状をなし $\mathrm{B}-\mathbb{I I}$ の変質である。

福島県石川町沢井〜浅川町白石のカンラン岩脈は, 筆 者の調查によると, 周辺部幅 1 数 $\mathrm{m}$ 間の破碎帯で, 蛇紋石化と滑石化が著しい。その变質帯に片岩化は認め られず，A－IIの変質である。

3）御荷鉾帯, 三波川帯

紀伊半島東部御荷鉾带の緑色岩類に伴う蛇紋岩は蛇紋 岩硞岩層で, 坂野8)のスケッチによると滑石, 方解石, 繊維状透閃石, 緑泥石加らなる滑石炭酸塩岩と青色片岩 は, 蛇紋岩礫岩層の中に挟在する堆積岩であり, D - I の変質である。

四国三波川帯白滝鉱山の滑石帯は, 幅約 $10 \mathrm{~m}$ の蛇紋 岩との境界沿いにあたかも蛇紋岩を包むように発達し, 特に下盤側では幅 1〜2 $\mathrm{m}$, 延長 $100 \mathrm{~m}$ 以上に及び, 片 岩とはすべり面で接する。白滝鉱山北の城師付近では, 蛇紋岩と下盤の片岩の間に滑石帯が形成され，幅 $1 \sim 2$ $\mathrm{m}$ で, 延長 $600 \mathrm{~m}$ に及ぶと見られる。この滑石帯は片 岩化しているものと推測され，A－正の変質である。

\section{4） 飛騨外縁帯}

青海一小滝帯新潟県姫川の蛇紋岩メランジェ（長谷川 ・小松9) について, 大村・他 ${ }^{100}$ は岩質状況から, 塊 状, 葉片状, 粘土状に区分している。周辺破碎带, 接触 部付近および蛇紋岩自身の滑石化と緑泥石化は, SEKI et al. ${ }^{11)}$ のスケッチから判断すると $10 \sim 20 \mathrm{~cm}$ 幅の小規 模なものである。この蛇紋岩メランジェは葉片状〜粘土 化しており，C-IIの変質である。

5）第三系

嶺岡帯の蛇紋岩化した超塩基岩類は, 網状に変質を受 けて石綿を生じ, 少量の滑石を伴う（前田・他 ${ }^{12)}$ )。

$\mathrm{JR}$ 嶺岡トンネルの地質は, 蛇紋岩, 頁岩ともに破碎 していて粘土化が著しい。そして，粘土化頁岩の X 線 回折によると，モンモリロナイトの含有率が高いことが わかった（緒方・金岡13)）。当地の蛇紋岩は堆積性メラ ンジェであり，D－ Iの変質である。

\section{3. 蛇紋岩の工学的性質}

\section{1 蛇紋岩地帯の代表的工事での工学的性質}

蛇紋岩地帯では, トンネル掘削の際大きな膨張性土圧 が発生し, 掘削後の支保が問題になることが多い。その 膨張性土圧は，池田 ${ }^{14)}$ によると新登川トンネルの場合 (C-II 相当と推定) で $13.0 \sim 14.0 \mathrm{kgf} / \mathrm{cm}^{2}$, 篠栗トン ネルの蛇紋岩・滑石片岩（A- III 相当）で $2.0 \sim 3.0$ $\mathrm{kgf} / \mathrm{cm}^{2}$, また小竹・他 ${ }^{15)}$ によると JR 神居トンネルで 最大土圧は $120 \mathrm{tf} / \mathrm{m}^{2}$ ，通常 $50 \mathrm{tf} / \mathrm{m}^{2}$ とされ，測定箇所 で変動が大きい。

小竹・他 ${ }^{15)}$ によると, JR 神居トンネルで強大土圧の 発生の原因となった地質は，蛇紋岩メランジェの粘土状 蛇紋岩, 葉片状蛇紋岩 (C - II相当) である。粘土状蛇 紋岩，あるいは葉片状蛇紋岩に取り込をれる塊状蛇紋岩 （C－Ｉ相当）は，殆ど土圧を発生させる原因にならな いと言われる。

総じて蛇紋岩岩体の掘削面周辺部の弾性波速度值は, 経時的に低下し，掘削直後 $3.4 \mathrm{~km} / \mathrm{s}$ であったものが 6 日後には $2.0 \mathrm{~km} / \mathrm{s}$ と変化した。掘削に伴う蛇紋岩体の 膨張量は, 半径 $1.2 \mathrm{~m}$ の馬蹄形断面で, 50 日後 $65 \mathrm{~mm}$, 100 日後 $110 \mathrm{~mm}, 200$ 日後 $130 \mathrm{~mm}$ を示した。地山か らの荷重は110日頃をピークに，その後は横這いあるい は減少する傾向が認められた。

また小竹・他 ${ }^{15)}$ は膨張量の測定を行い，水中でも空 気中でも約 $20 \%$ の膨張を示す結果を得て, 膨張は風化 による弛緩と自由面形成による応力解放の時間的な遅れ による緩みに原因があるものと解积した。その応力解放 は塑性領域の拡大とその塑性流動によって行われると述 ベている。

喜田・辻 ${ }^{16)}$ によると, 京都府河守線辛皮トンネル工 事で膨張性土圧を発生させた夜久野複合岩類 (B タイプ) の風化蛇紋岩の粘土鉱物は, クリソタイルとアンチゴラ イトで，一部緑泥石，さらに加水石膏と滑石を含む。表 -1 の試料の組成鉱物から変質度を推測すると, No 1 , No 2 は葉片状〜粘土状を示し B - II，No 3 は塊状をな すので B - I である。これらの蛇紋岩風化部分は，可塑 性と粘着力に乏しく，粘土粒子間の結合も弱いため僅か な水分増加で容易に剪断を受け流動化（塑性流動）しや すい。表-1の土質試験結果は, 塑性指数 $\left(I_{\mathrm{P}}\right)$ が Max. 14.6, 活性度 $(A)$ が Max. 0.53 と，ともに極め て低い值であり，その性質をよく示している。

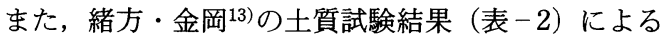
と, 嶺岡トンネルの粘土化蛇紋岩（D-II相当）は，自 然含水比がモンモリロナイト高含有の粘土化頁岩, 粘土 
表-1 辛皮一普甲ずい道の風化蛇紋岩の土質

(喜田・辻16) から引用)

\begin{tabular}{|c|c|c|c|c|c|c|c|}
\hline 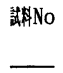 & 岩質 & $\begin{array}{l}\text { 構成鉱物 } \\
\text { 要 锥 }\end{array}$ & 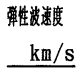 & $\mathbb{N}_{L} \%$ & $\begin{array}{l}\text { コンシス } \\
\text { WP } 8\end{array}$ & $\begin{array}{r}\text { ジー } \\
\mathrm{I}_{\mathrm{P}} \\
\end{array}$ & A \\
\hline No. 1 & $\begin{array}{l}\text { 粘土状 } \\
\text { 葉片状 } \\
\text { 極軟質 } \\
\end{array}$ & $\begin{array}{l}\mathrm{Cr} \\
\mathrm{ch} 1, \mathrm{Tl}\end{array}$ & 2.7 & 45.0 & 30.4 & 14.6 & 0.53 \\
\hline No. 2 & $\begin{array}{l}\text { 葉片状 } \\
\text { 塊状 } \\
\text { 軟質 }\end{array}$ & $\begin{array}{l}\mathrm{Cr} \\
\mathrm{Ch1}, \mathrm{T} 1 \\
\end{array}$ & 4.7 & 41.8 & 32.3 & 9.5 & 0.42 \\
\hline No. 3 & $\begin{array}{c}\text { 塊状 } \\
\text { 一部葉片状 } \\
\text { 硬質 }\end{array}$ & $\begin{array}{l}\mathrm{Cr}, \text { Ant } \\
\mathrm{Chl}\end{array}$ & 5.5 & 23.5 & 22.5 & 1.0 & 0.09 \\
\hline
\end{tabular}

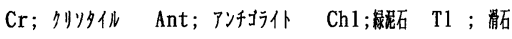

質岩の値と差のない $7.4 \sim 13.1 \%$, 吸水膨張率は同粘土 化頁岩の值の約 2 倍 $2.5 \sim 5.5 \%$, 塑性指数は同粘土化頁 岩, 同粘土質岩と比べて非常に低い值の19.2である。

この試験結果から，モンモリロナイト高含有の粘土化 頁岩，粘土質岩と比べ塑性指数が低いにも関わらず，粘 土化蛇紋岩は比較的高い自然含水比, 吸水膨張率を示 し, 吸水膨張を行っていることも考えられる。

\section{2 三郡山北部の変成岩中蛇紋岩の工学的性質}

B - I の変質を受けている大岩脈は, 弱い片理構造を 示し，一部で葉片状に破断した蛇紋岩は風化している が, 周辺のクリソタイル細脈を伴う変輝緑岩と角閃石片 岩に比べ風化に対する抵抗は強く, 尾根部を形成し岩塊 が露出していることが多い。変輝緑岩と角閃石片岩は網 目状の割れ目に沿い風化し，角䃯を含む粘土化帯を形成 している。

そのため蛇紋岩周辺の変質帯に沿って地すべりや岩す ベりを起こしやすく，地形の等高線は乱れている。蛇紋 岩は風化すると表面剥離を生じ, 棟瓦色の特徵的な土壤
となる。この風化土䗙は, 粘性, 含水比の高いものが多 い。蛇紋岩は硬岩と区分されることが多いが，割れ目に 沿う岩盤の滑落, 岩盤膨脹による張出しに十分な注意が 必要である。

$\mathrm{A}$ - IIIの滑石片岩は, 新鮮部は板状の堅固な岩石であ る。蛇紋岩側では全般に圧砕されているため燐片状に剝 離し滑りやすいが, 滑石片岩中心部でも風化すると燐 片, 粉末状となり粘土化〜土壤化する。滑石片岩の風化 は地表下 $5 \sim 10 \mathrm{~m}$ に及び, 一般に自然含水量が高く地 すべりの原因になりやすい。

同じ $\mathrm{A}-$ III に属する緑泥石片岩は, 風化が片理面や 断層にそって進行し，また若干の滑石鉱物を含むので， 風化部では表層すべりが起きやすい。

\section{3 鉱物学的検討}

一般に粘土鉱物は, 鉱物化学的にフィロ珪酸塩と総称 される。結晶構造は図-5 に示す $\mathrm{Si}-\mathrm{O}$ の四面体が結合 して四面体層を作るが, 格子間の結合は弱いと推定さ れ，一部 $\mathrm{Si}$ が $\mathrm{Al}, \mathrm{Fe}, \mathrm{Mg}$ で置換される層は八面体層と なる $\left(\right.$ 須藤 $\left.{ }^{17)}\right)$ 。

蛇紋石（クリソタイル・アンチゴライト）, 滑石, 緑 泥石は, 図-5に示すフィロ珪酸塩鉱物の層構造を持 ち，鉱物学上は粘土鉱物として取扱われる。水の取込み 方は層格子間での吸着水と結晶水である。粘土鉱物が親 水性を示すのは, 層格子間の $\mathrm{OH}$ 基と結晶水の存在に 大きく起因する。

蛇紋石, 緑泥石とモンモリロナイトの層格子間には, $\mathrm{OH}$ 層, $\mathrm{H}_{2} \mathrm{O}$ 層が存在し親水性が大であるため水分子 が入りやすい。帯電した水分子が層格子間には入り込む ことにより膨潤が始まる。

滑石は層格子間が電気的に中性のため層間結合は弱く 破断しやすく，すべりやすい。

緑泥石は変質鉱物として最も一般的な鉱物の 1 つで

表 - 2 嶺岡トンネルにおける土質（緒方・金岡 $\left.{ }^{13}\right)$ による）

\begin{tabular}{|c|c|c|c|}
\hline 項目 単位 & 粘土化蛇紋岩 & 粘土化頁岩 & 燐片状粘土質岩 \\
\hline 洜比 $\left(w_{n}\right)$ & 7. $41 \sim 13.05(9.45)$ & 7. $15 \sim 15.31(11.49)$ & 9. 33 16.06(12. 89) \\
\hline 密度 $(\rho \mathrm{t}) \mathrm{g} / \mathrm{cm}^{3}$ & $2.00 \sim 2.33(2.11)$ & $1.90 \sim 2.25(2.11)$ & $2.01 \sim 2.23(2.13)$ \\
\hline 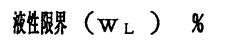 & $35.2 \sim 53.0(44.0)$ & $42.5 \sim 52.0(47.3)$ & $33.0 \sim 55.9(44.8)$ \\
\hline 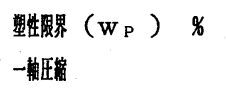 & $21.9 \sim 26.8(24.8)$ & $17.3 \sim 22.7(20.0)$ & $16.0 \sim 27.1$ (21. 1) \\
\hline$(q u) k f g / \mathrm{cm}^{2}$ & $2.65 \sim 26.07(10.0)$ & $1.34 \sim 3.41(2.28)$ & $0.62 \sim 7.01 \quad(2.64)$ \\
\hline 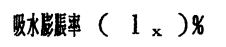 & $2.48 \sim 5.46(3.52)$ & $0.98 \sim 2.89(2.14)$ & $1.11 \sim 5.83(3.86)$ \\
\hline
\end{tabular}


表 - 3 蛇紋石, 滑石, $\mathrm{Mg}$ 緑泥石の化学式 ただし $\mathrm{a} ; 11 \sim 8, \mathrm{~b} ; 1 \sim 4, \mathrm{c} ; 7 \sim 4$

\begin{tabular}{|c|c|c|}
\hline & 酸化物式 & 構造式 \\
\hline 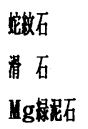 & $\begin{array}{l}3 \mathrm{MgO} \cdot 2 \mathrm{SiO}_{2} \cdot 2 \mathrm{H}_{2} \mathrm{O} \\
3 \mathrm{Mg} 0 \cdot 4 \mathrm{SiO}_{2} \cdot \mathrm{H}_{2} \mathrm{O} \\
\mathrm{aMg0} \cdot \mathrm{bAl}_{2} \mathrm{O}_{3} \cdot \mathrm{CSiO}_{2} \cdot 8 \mathrm{H}_{2} \mathrm{O}\end{array}$ & 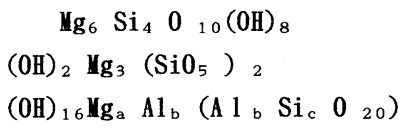 \\
\hline
\end{tabular}

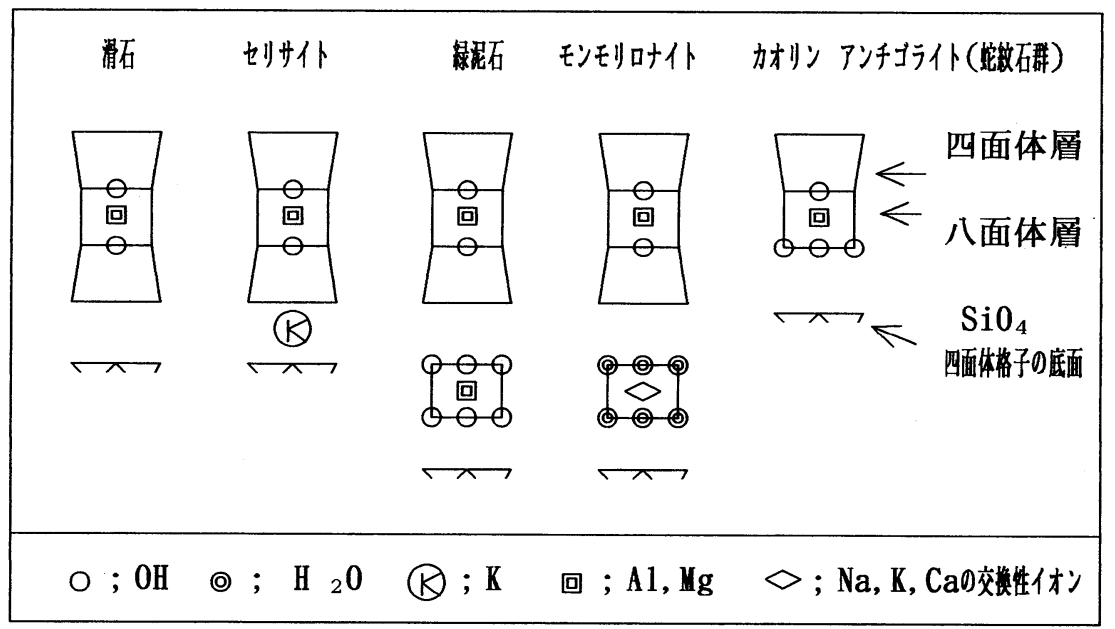

図-5 粘土鉱物の層構造図（須藤17)の図引用）

あるが，その種類と化学組成は複雑である。 $\mathrm{Mg}$ 緑泥石 は，素木 ${ }^{18)}$ によると膨潤性，粘性が極めて大きく，モ ンモリロナイトに類似するが，その割合に可塑性の小さ いことが特徵とされる。池田 ${ }^{14}$ による篠栗トンネル内 蛇紋岩・滑石片岩部試料のX 線回折結果によると, 主 要粘土鉱物は $\mathrm{Mg}$ 緑泥石と記録されている。

これまで蛇紋岩から $\mathrm{Mg}$ 緑泥石が多量に鑑定された 例は少ないが，粘土化蛇紋岩と片岩化蛇紋岩は $\mathrm{Mg}$ 緑 泥石の生成に適した変成状況にあるものと考えられる。 蛇紋石，滑石と $\mathrm{Mg}$ 緑泥石の $\mathrm{Mg}$ に富む 3 鉱物は，表一 3 の通り極めて近似した酸化物式と構造式である。今 後，蛇紋岩の工学性を検討するに当たっては， 3 鉱物の 有無とその性質を調査する必要があると考える。

蛇紋岩の膨張は，3.1節で工学的事例を検討したが， 鉱物学的には風化や自由面形成による潜在応力の解放に よって発生する。また，応力解放に起因する蛇紋岩变質 鉱物の層構造組織である葉片状構造の緩內は，塑性領域 の拡大と塑性流動，あるいは水の浸透による吸着が誘因 となって吸水膨張を生じると考えることができる。 蛇紋岩に働いた構造運動に起因する剪断力は図ー6に

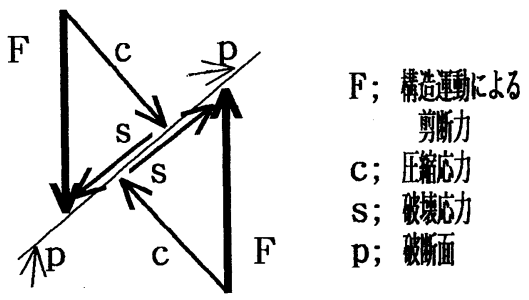

図－6 構造運動時の蛇紋岩の受けるストレス

示すような破壊応力（s）を生み，粘土状，葉片状蛇紋 岩, あるいは滑石〜緑泥石片岩の片理, あるは片理に平 行する破断面（p）を形成し，ストレスはほとんど消隇 していると考えられる。一方その剪断力 $(F)$ の分力は 強大な圧縮応力 $(c)$ として作用し, 結晶構造内に残存 している。

応力解放は, 破断面に平行する圧縮面を構成する葉片 状構造・片理面の緩及から始まる。葉片状構造や片理面 を詳細に測定することは，压縮面に垂直に作用すると考 えられる膨張性土圧の最大方向を予測する上で重要であ ると考える。 


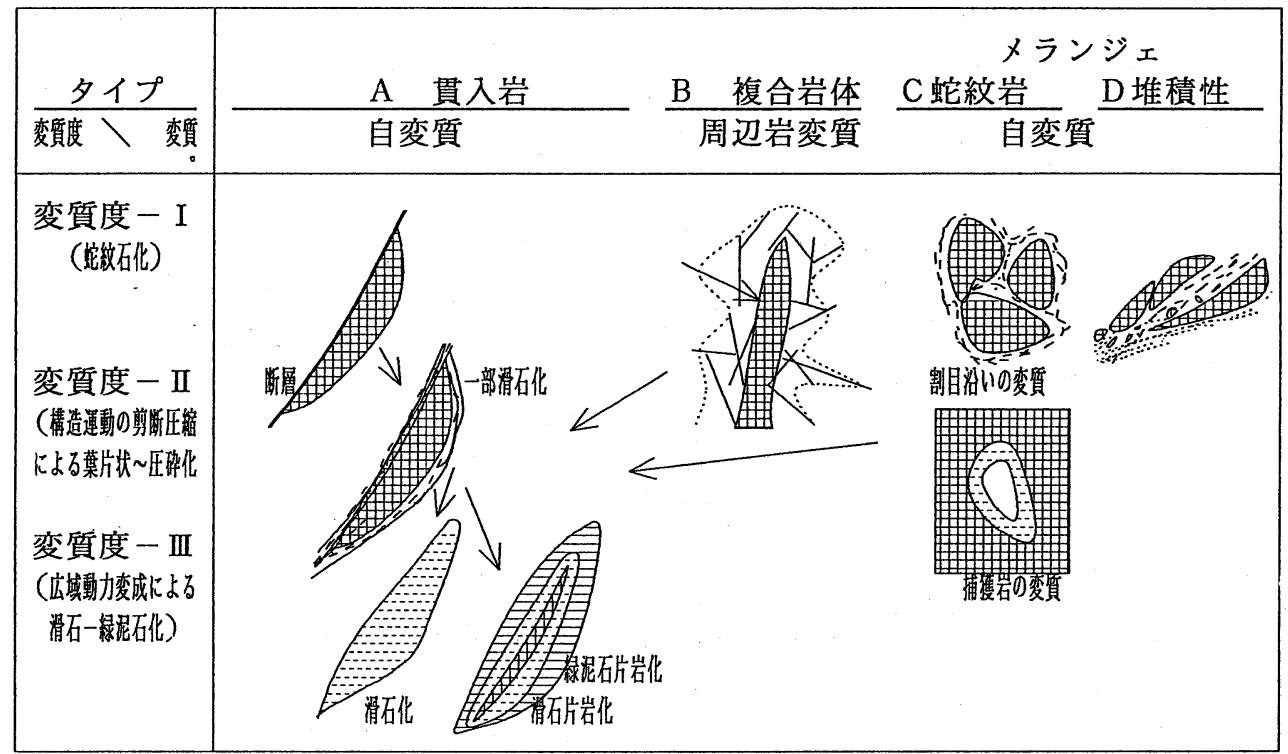

図-7 蛇紋岩化作用の形態分類

\section{4. まとめ}

1）蛇紋岩化作用に伴う粘土鉱物

構造運動による蛇紋岩化作用で生じる蛇紋石（クリソ タイル・アンチゴライト), 滑石, 緑泥石は, 粘土鉱物 学的に極めて類似した化学式と構造式を持っている。こ れらの鉱物は, 土粒子間の結合が弱い, 可塑性, 粘着力 に乏しい, 塑性指数が極めて低い, また, 僅かな水分増 加で容易に膨脹し流動化しやすい等, ほぼ共通した性質 を持っている。

滑石化した岩石は風化すると燐片あるいは粉末状とな り崩壊し，粘土化〜土壤化する。また，自然含水量が高 く地すべりの原因になりやすい。

$\mathrm{Mg}$ 緑泥石は，モンモリロナイトに類似する鉱物的性 質を持っているため膨潤珄がある。

蛇紋岩調查では, こうした蛇紋石, 滑石, $\mathrm{Mg}$ 緑泥石 等の粘土鉱物の分布状況や片理面を把握できるように心 掛ける必要がある。

2）蛇紋岩について

以上, 蛇紋岩のタイプと変質について検討したことを 総括すると，蛇紋岩化作用の形態は図 -7 のように分類 できる。蛇紋岩調査に際し，どのような産状タイプの蛇 紋岩で, どの変質度にあるかを把握することは大事であ る。

図-7は各タイプの蛇紋岩化作用の過程を, 蛇紋石 （塊状蛇紋岩）の生成一葉片状 - 圧砕化 ·粘土化一片岩
化に分類して図示したものである。しかし, 変質度が進 行するにつれて各タイプ岩体は圧砕しブロック化するた め, $\mathrm{A}$ タイプと同じ変質の形態になるものと考えられ る。Cタイプの蛇紋岩化作用は割れ目沿いに限らず，捕 獲岩の境界沿いにも形成される。

難工事例は変質度 II の岩盤が多い。構造運動による二 次的な強い剪断圧縮を受けた葉片状蛇紋岩・粘土状蛇紋 岩は, 潜在する応力が解放することで強大な土圧を発生 させる。応力開放の結果として生じる剥離面の増大は吸 水膨脹を促進し, 塑性領域を拡大させ, 塑性流動を生じ ると考えられる。

変質度吕の岩盤の場合は, 応力開放で生じた滑石片岩 ・緑泥石片岩の岩片を含む土粒子部分の塑性流動と $\mathrm{Mg}$ 緑泥石による膨潤が原因になるものと推測される。篠栗 トンネルは片岩地帯における唯一の事例であるので, 変 質度IIIの貴重な参考例である。变質度 II の岩盤に比べて 工事例の少ないことが難工事例の少ない原因ではないか と考えられる。

変質度 I の岩盤は，主に土圧発生の原因にならないと 考えられる塊状蛇紋岩であるので難工事例は少ない。

以下, 蛇紋岩のタイプ・変質度 ·それに関連した工事 例と岩体を示す。図-8は，わが国に産する蛇紋岩と， 事例の蛇紋岩のタイプ一変質度を地質構造図上に示した ものである。

\section{A タイプ}

変質度 II 例 ; 富内線地すべり, 福島県浅川 


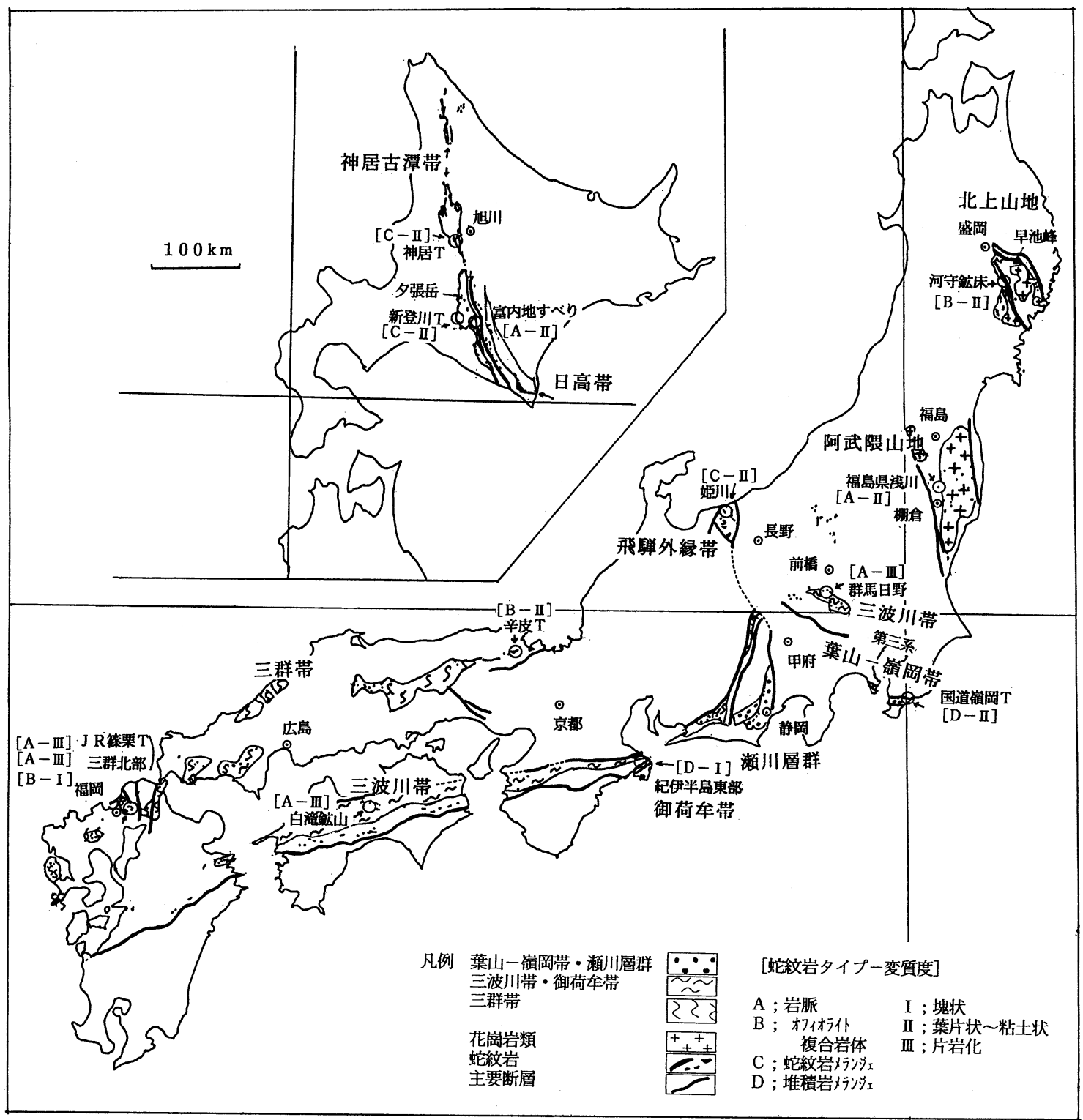

図 - 8 わが国地質構造帯に分布する蛇紋岩と工事簓所蛇紋岩のタイプと変質度 地質調査所, 日本地質図 (1978) より作成

変質度 III 例 ; 群馬日野, 四国白滝滑石鉱床, 三郡山北部，JR 篠栗トンネル

B タイプ

変質度 I 例 ; 三郡山北部

変質度 II 例 ; 北上宮守滑石鉱床, 辛皮トンネル

Cタイプ

変質度 II 例 ; JR 神居トンネル, 新潟県姫川, 新登川トンネル
D タイプ

\section{変質度 I 例 ; 紀伊半島東部御荷牟帯}

変質度 II 例 ; 国道嶺岡トンネル

蛇紋岩化作用の形態分類は文献資料に基いた。今後も 現場おける蛇紋岩の膨張について, 鉱物学的な追及と現 場の調査資料を数多く加えてさらに充実したものとし, 膨張性土圧あるいは斜面安定の対策検討のために効果的 な調査とコンサルティングができるようにしてゆきた い。 


\section{参 考 文 献}

1）石渡 明 (1993):オフィオライト 日本地質学会, 日本 の地質学 100 年 pp. $155-160$.

2) 斎藤昌之 (1958) : 蛇紋岩化作用と温石綿の形成, 鈴木醇 教授還暦記念論文集 pp. $421-432$.

3）辻慎太郎（1964）: 福岡県篠栗・香椎地方に分布する三郡 変成岩, 地質学雑誌 Vol. 70, pp. 483-492.

4) NAGASAWA, M. and TODA, H. (1987): GEOLOGY \& PETROLOGY OF YUBARI-DAKE SERPENTINITE MERANGE IN THE KAMUIKOTAN TECTONIC BELT, CENTRAL HOKKAIDO, JAPAN, THE JOURNAL of THEGEOLOGICAL SOCIETY of JAPAN, Vol. 93, pp. $733-748$.

5）酒井 彰（1990）: 岩知志周辺の “未分離日高累層群”，共 立出版社，日本の地質 1 「北海道地方」 pp. 29.

6）山田剛二・守山信一・西尾国重 (1969): 富内線地すべり の調査と対策一地すべり面と地すべり土塊の運動, 鉄道 技術研究報告, No. 463. Sep..

7）蟹沢聰史 - 大上和良・永広昌之 (1992) : 早池峰複合岩類, 共立出版社，日本の地質 2 「東北地方」 pp. 44-45.

8) 坂野靖行 (1992): 紀伊半島東部, 御荷牟緑色岩類に伴う 蛇紋岩碟岩中の青色片岩, 岩鉱誌 Vol. 87, pp. $207-$ 220.

9）長谷川美行 - 小松正幸（1986）: 飛騨外縁帯, 共立出版社, 日本の地質 4 「中部地方」 pp. 7-10.
10）大村一夫 - 山地英喜 - 岩㭇 修 - 吉田亘弘 - 山戸武史 (1983) : 新潟県姫川地域の蛇紋岩. 一一岩盤評価の前に 応用地質 VOL. 24, PP. 97-112.

11) SEKI, Y. KURIYAGAWA, S. and HORIKOSI, T. (1963): Mafic and Leucocratic Rock associated with Serpentinites in the Sasaguri and Omi-Kotaki areas in the Sangun Metamorphic Belt of Japan, Science Rept. Saitama Univ., Ser. B, 4, (3), pp. $193-216$.

12）前田四郎 - 根本敬義・前田紘志 - 他 (1980): 千葉県地学 のガイド コロナ社, pp. 34-40.

13）緒方義久・金岡一夫 (1972) : 蛇紋岩トンネルの施工一国 道128号線嶺岡トンネル, トンネルと地下 Vol. 3, No. 3.

14）池田和彦（1974）: 岩の工学的性質と設計・施工への応用 一トンネルへの応用, 土質工学会, pp. 419.

15）小竹 豊・鈴木和也・溝畑靖雄 (1969) : 蛇紋岩トンネル の特性とその設計施工，一国鉄神居トンネルの例，土木 学会誌 $54-8$. pp. $45-51$.

16）喜田大三・辻 博和 (1973) : ずい道工事における風化蛇 紋岩の土質化学的検討, 粘土科学, Vol. 13, pp. 65-73.

17）須藤俊男 (1959) : フィロ珪酸塩, 共立全書, 鉱物化学II, pp. $215-232$.

18）素木洋一（1953）: 鰝淵産緑泥石の性質, 宰協, Vol. 61, pp. $485-490$.

(1995年 3 月 14 日受付, 1995年 8 月23日受理） 